\title{
Research on Construction and Management of College English Extracurricular Activities in Science Universities
}

\author{
Yu Yang \\ Faculty of Foreign Languages and Literature Kunming University of Science \& Technology Kunming, Yunnan Province, China \\ yangyu589@126.com
}

\begin{abstract}
Extracurricular learning is one of the most important parts of the whole teaching and learning system. And a lot of universities have constructed their own college English extracurricular activities in order to improve students' competence in English, especially speaking and listening. In this paper, a survey on English extracurricular activities in science universities is conducted to explore students' understanding on extracurricular activities and assessment on management of those activities in universities. The result shows that there are still some problems in the practice of extracurricular activities and students are not quite satisfied with these. Finally, some countermeasures are discussed from perspective of management.
\end{abstract}

Index Terms - college English extracurricular activities, management, science universities

\section{Introduction}

Extracurricular learning is one of the most important parts of the whole teaching and learning system. The target of college English teaching and learning is to cultivate college students' comprehensive ability of using English, especially the ability of listening and speaking; enable them to effectively use English orally and in written form to communicate with people in work and social interactions. College English Course Teaching Requirements' emphasis on comprehensive practical ability on listening and speaking ability and on autonomy ability leads Chinese college English teaching and learning to a new era. However, where do comprehensive practical ability, speaking, listening ability and autonomy ability come from? Four hours classroom teaching per week is far from enough. More efforts should be put into extracurricular English activities so that students can have better environment and more chances to use English and improve it.

A lot of previous study has focused on the topic of college English extracurricular activities. Zhou Hongyue (1994) suggested that setting up language labs, freely open to students, should be the base for designing extracurricular activities and these labs are the ideal places for students' afterclass learning. After that, many teachers and researchers found that extracurricular activities could take in all kinds of forms. Wang Lingkun (1997) collected the data on the correlation between English test scores and participation in extracurricular activities in order to show that with these out-of-class activities students made great progress in English learning. Zhou Ping (1999) drew the conclusion that extracurricular activities can be the supplement to classroom teaching. Different extracurricular activities were designed to improve college English teaching. Nan Fan (2002), using his teaching experience, introduced several forms of extracurricular activities. People also collected the results of organizing extracurricular activities. Li Yan \& Wang Guimin(2005) put that extracurricular activities can promote students' competence in listening and speaking by experiments. Deng Qi(2007) tended to construct a framework of college English extracurricular activities from the perspective of constructivism by taking Chongqing University as an example. Cao Xuehua and Wei Na (2008) indicate that extracurricular English learning activities are the extension and auxiliary form of English classroom teaching. Qu Hong (2010) found that natural language learning environment can increase the students' interest and confidence in learning language.

As a result, extracurricular activities have received more and more recognition. However, few study has been conducted on the cognition and understanding on extracurricular activities of students, especially for students in science universities. Therefore, this paper aims to explore students' understanding on extracurricular activities and assessment on management of those activities in universities.

\section{Research Questions And Design}

In this paper, three research questions are discussed as follows.

(1) How much do students in science universities know about college English extracurricular activities?

(2) How often do they participate in extracurricular activities and how is their plan in these?

(3) What are their responses and feedbacks on the management of extracurricular activities in their university?

To explore answers of the research questions, we design a questionnaire of 30 questions, which include two parts. The first part is made up of subjects' personal information, such as gender, major, English proficiency. The second part covers aspects of students' understanding of extracurricular activities, current situation of their actual participation in these activities, and their assessment on management of these activities in university.

A total of 500 questionnaires were distributed to the students in Kunming University of Science and Technology in their dormitories. And 483 valid questionnaires were finally collected. 


\section{Results}

\section{A. Students'understanding of college English extracurricular activities}

Since college English extracurricular activities are of great importance in our English learning and teaching, it is advisable for universities and teachers to encourage students to participate in these activities. However, whether students have a good understanding of college English extracurricular activities is not clear. To improve the efficiency of activities management in universities, we tend to find out how students know college English extracurricular activities.

(1) Knowledge about extracurricular activities.

When students are asked to define college English extracurricular activities, a lot of answers are offered. Among them, about $75 \%$ of students agree that any activity concerning English outside English classes can be regarded as English extracurricular activities, while $13 \%$ of students think only amusing activities like English drama performance, English Singing Contest can be classified as college English extracurricular activities. In addition, $12 \%$ of students are not certain about the definition of English extracurricular activities and think it is difficult to give a right definition.

(2) Lists of English extracurricular activities.

When students are asked to list out English extracurricular activities in the university, a lot of activities are mentioned. For example, Cultural Experience Week hosted by faculty of foreign languages and literature, English drama performance, "CCTV Cup" speech contest, English calligraphy contest, IQ test in English, NECCS (National English Contest for College Students), English lectures and English autonomous learning on network platform in universities.

\section{B. Students' actual participation in college English extracurricular activities and their plans}

Nowadays, a lot of national level English contests have been popularized, which offers a great platform for college students and stimulates students and teachers to participate in them. Meanwhile, much time and work have been put in construction of college English extracurricular activities to establish an atmosphere of English learning with the increasing importance of English in job-hunting market. However, whether students have an initiative to participate in such kind of English extracurricular activities is not found yet.

Firstly, students are asked to answer the question "Do you often participate in English extracurricular activities held by faculty or university? ". Only $8.2 \%$ of students choose the answer "Yes, I usually do"; $49.3 \%$ of students say they rarely participate such activities. And $42.5 \%$ of students say they have ever tried to take in this kind of English extracurricular activity once. From above data, it can be safely concluded that more students in science university still need to be encouraged to be participants in English activities.

Then, question about whether students have any plan when participating in English extracurricular activities is discussed. The result shows that only $4.6 \%$ of students have scientific and sound plan while $57.2 \%$ of them have plans but are not certain if they are reasonable. $36.1 \%$ of students say they do not have any plan and want to make one in the future and $2.1 \%$ of them have no plan at all in taking part in College English Extracurricular activities.

In addition, the underlying reasons why they do not participate in activities are explored. Among them, 31.6\% of them agree that they do not know any information on these activities. And $27.9 \%$ of them choose "I am not interested in college English activities." Apart from this, the reason that they do not have time to participate in activities accounts for $24.5 \%$. Still $16 \%$ of students in science university think the organizers do not design and arrange activities well so that they do not have desire to participate. From this, we can find that management of college English extracurricular activities needs to be improved to attract more students. At the same time, it is of great importance for teachers to take the design, goal and specific arrangement of activities into consideration when launching a kind of contest or performance.

The reasons for students' lacking scientific plan are partly because they do not have a clear idea about the importance and significance in their English learning. Also lacking guidance and help in participating in activities result in their messy plan.

\section{Students'assessment on management of college English extracurricular activities in science university}

It is generally acknowledged that management of college English extracurricular activities in university play an indispensible role in promoting those activities. That is why we tend to discuss students assessment on management in this paper. In question "Are you satisfied with college English extracurricular activities in your university? ", 50.2\% say they are not satisfied, while only $11.1 \%$ show they are very satisfied with this. Additionally, 6.55 of them say they do not care about this. For question "Do you think university has offered you enough opportunities for you to get access to college English extracurricular activities?", 45.4\% of students say "No", and $27.5 \%$ of them say "Yes". The rest of them show that they can participate in activities in university once or twice in one semester.

As is above discussed, majority of students in science university show their dissatisfaction with management of university and they want more chances to participate in college English extracurricular activities.

When asked "Is there any correlation between your English proficiency and college English extracurricular activities?", most of students (70.8\%) show that college English extracurricular activities are conducive to improvement of their English competence. 18.6\% of students say they do not benefit from these activities. From this, we can find that students have realized and asserted the positive influences of college English extracurricular activities on their English learning, which really facilitate their English study and help to enhance their comprehensive competence of their English. But on the other hand, they are not quite satisfied with the global effects of college English extracurricular activities. 
Therefore, it is feasible for activities organizers to create a free and relaxing atmosphere for students by designing different forms of activities to stimulate students interests in them, then attaining the goal of improving their English proficiency.

To find specific information on underlying problems of college English extracurricular activities in science university, students are asked to make comments on these activities and pin out the biggest problem in management of college English extracurricular activities in science university. Only $14.9 \%$ of students think that management of college English extracurricular activities in science university is scientific and systematic while $43.1 \%$ of them think those activities are not well-organized. When asked "What is the biggest underlying problem of college English extracurricular activities in science university?", $36.1 \%$ of students say they cannot get good, systematic guidance from teachers when participating in activities. And $26.3 \%$ of them say there is no relaxing atmosphere for students in university.

\section{Analysis And Discussion}

Based on above-mentioned data, we can find that students in science university are not satisfied with current situation of management of college English extracurricular activities. And there are still some problems such as disorder in design and organization of such activities, unscientific and unsystematic arrangement of activities, lack of effective propaganda for activities, inadequate teachers and money.

Therefore, some countermeasures are discussed to solve the above problems in order to improve the effectiveness and efficiency of college English extracurricular activities.

\section{A. Make up definite goals in designing activities and raise students' interests in participation.}

Some of college English extracurricular activities in science university might not be able to develop students' specific language abilities because of their lack of a very specific or direct purpose when they are designed. Therefore, the more detailed learning objectives should be set in the designing stage. Then students' interests can be promoted.

Psychologists have proved that interest, as a nonintellectual factor, may greatly increase students' positivity and initiative of learning. In order to boost the education quality, improve the efficiency and have a good result of the English teaching, English teachers should truly get the real interests of students in learning English and carry out series of English teaching activities in accordance with students' real interests.

This is why we need to take students' interests into consideration and organizers need to organize an activity directed by the real interests of students instead of the teachers. Before and after the activities, it is necessary for teachers and organizers to make a logical analysis of students' different interests and feedbacks. Then we can design different forms of activities to satisfy students' various interests.

Taking speech contest for example, some students may feel shy to speak English out in public while their writing in
English is quite excellent. At this time, another form of activities like college English writing test is more preferable and reasonable for them to participate in .

In a word, we need to make up definite goal in designing each activity so that students with different level of English proficiency can maintain interests to be one of participants. College English extracurricular activities have the distinctive characters of flexibility and variability in forms and contents. New forms are still being created during the constant practice. For example, English corner, English extracurricular activities groups, English singing contest, reading competition on Internet. Besides these, role-plays, English parties, English broadcastings, or English lectures are all effective ways to stimulate students' interests in learning English.

Furthermore, it is also worthwhile to make a further study on exclusion of college English extracurricular activities from the syllabus, which are not fit for the objectives; otherwise they may have a negative impact on students learning. For instance, if some of activities are too difficult to some extent, they should be deleted immediately, for it will cause students' fear of attending English extracurricular activities.

\section{B. Train English teachers to offer more specific and facilitating guidance in college English extracurricular activities.}

English teachers play a vital role in helping students perform better in college English extracurricular activities. With their right guidance, students can avoid a lot of mistakes and get satisfactory rewards more easily. However, sometimes English teachers cannot combine what students have learned in English class with those English activities outside class, which will hinder the development of students' English competence. Meanwhile, some teachers are uncertain about the guiding principles in real practice and lacking in experience in specific situation. For example, in English drama show, skills to show their emotions and spirits in drama are quite important, while English teachers do not have suck kind of experience and have to focus on language itself only. This may reduce the beauty of performance.

As a consequence, English teachers are in great need of special training on how to guide students better and more effectively in actual activities and how to cultivate practical skills in helping students in different forms of activities.

\section{Set up funds in organizing college English extracurricular activities.}

Nowadays, a lot of universities are confronted with a lot of challenges such as limited reference books or materials for students and teachers, inadequate money to invite specialist and experts to give lectures or offer professional training for contest candidates, lack of special space for organizing activities. To ensure the smooth, systematic and long-term development of extracurricular activities, we need to set up special and fixed funds, which can help teachers to buy some books or videos and organizers to rent specialized place.

Guaranteed by fixed fund, science university can construct a systematic and scientific framework of college 
English extracurricular activities in the long run and invite professor to give teacher and students more practical skills. In this way, teachers and students may have initiatives in participation because they can really benefit a lot from these activities. Meanwhile, a small amount of fund can be spared to reward those candidates who won prizes in competitions or activities and their guiding teachers. This will help to boost students' and teachers' enthusiasm in such kind of English extracurricular activities, which can offer a platform for teachers and students.

\section{D.Establish assessment system on college English extracurricular activities and collect students' feedback on them in time.}

After activities are completed, we can assess their effects and collect students' feedback on them in time. Normally, a large number of questions can be raised as follows. Can college English extracurricular activities organized by teachers or university create a relaxed learning atmosphere and flexible forms? Are their contents are more interesting? Will students master the knowledge from these activities more easily? Or are these activities attractive to students?

Through these questions, the significance and importance of college English extracurricular activities will be emphasized and organizers can adjust their arrangements next time to make up for any mistakes or unreasonable actions. And by time and practice, an assessment system can be established to guide their management of college English extracurricular activities.

\section{E. Specify principles in management of college English extracurricular activities and create a relaxing atmosphere for teachers and candidates.}

College English extracurricular activities do have impact on students' achievements in English learning, especially for the students who took part in it with a high frequency, its effect is more significant. Therefore, to specify guiding principles on participants, teachers and organizers is a must for university. By them, teachers, participants and organizers can communicate well and get along with each other very harmonious, because their corresponding responsibilities and duties are clearly identified. Then a kind of relaxing and friendly atmosphere can be set up in specific competition.
With these guiding principles, every step of such English extracurricular activities can be controlled and guided scientifically. Even any problems appear, a real-time response can be made to resolve it.

\section{Conclusion}

College English extracurricular activities are of great value in complementing normal English teaching in class. Their systematic development demands constant study and practice. It is advisable for university to set up a sound management system in organizing such activities and develop various forms of them to attract more students to participate in. Meanwhile, our English teachers also need to improve our teaching methods continuously to make full use of the English extracurricular activities, enhancing students' English comprehensive proficiency greatly in science university.

\section{Acknowledgment}

The study is supported by the College English Teaching Reform Fund in Yunnan (Yunnan Higher Education [2013] 40).

\section{References}

[1] Cao, X. Y., \& Wei, N. (2008). The Cultivation of Student's English Quality and Communicative Competence under the Assistance of Extracurricular Activity. Journal of Tonghua Normal University, 29(1), 70-72.

[2] Duffy, T. M. (1991). Designing Environment for Constructivist Learning. New York: Springer-Verlag.

[3] Gilliam, P. (2001). Extracurricular Activities for Japanese Students. Review of Research in Education, (7), 268-274.

[4] Guo, F. P. (2006). An Empirical Study of Using Extracurricular Activities for Extending College English Teaching. Unpublished master's thesis, Southeast University, Nanjing.

[5] Nan, F. (2002). On the Forms of After-class Activity and Assistant Teaching Methods. Journal of Hebei Engineering \& Technology Vocational College, 4(1), 19-21.

[6] Qu, H. (2010). A Study of Extracurricular Activities in Secondary Vocational School English Teaching. Unpublished master's thesis, Shandong Normal University, Jinan.

[7] Rombokas, M. (1995, October). High School Extracurricular Activities and College Grades. Paper Presented at the South-eastern Conference of Counselling Personnel, Jekyll Island, GA. (ERIC Document ED391134)

[8] Wang L. K. (1997). On Extracurricular Teaching of College English. Foreign Language World, (3), 54-57.

[9] Zhou, H. Y. (1994). Language Labs and After-class Teaching. Shandong Foreign Language Teaching Journal, 3(4), 23-26. 